\title{
The Epstein-Barr Virus Early Antigen Inducing Indole Alkaloids, (-)-Indolactam V and Its Related Compounds, Produced by Actinomycetes
}

\author{
Kazuhiro Irie, Mitsuru Hirota, Nobuyuki Hagiwara, \\ Koichi Koshimizu, ${ }^{\dagger}$ Hideo Hayashi, ${ }^{*}$ Sawao Murao, ${ }^{*}$ \\ Harukuni ToKUDA** and Yohei ITO** \\ Department of Food Science and Technology, Faculty of Agriculture, \\ Kyoto University, Kyoto 606, Japan \\ *College of Agriculture, University of Osaka Prefecture, \\ Sakai 591, Japan \\ **Department of Microbiology, Faculty of Medicine, \\ Kyoto University, Kyoto 606, Japan
}

Received October 25, 1983

\begin{abstract}
Two indole alkaloids which induce the Epstein-Barr virus early antigen of Raji cells (B lymphocyte) were found in the cultured broth of Actinomycetes NA34-17, from which teleocidin B was also obtained. The active compounds isolated were identified from their spectral data and chemical evidence as (-)-indolactam $\mathrm{V}$ and $(-)$-14- $O$-acetyl indolactam $\mathrm{V}$.
\end{abstract}

Chemical carcinogenesis has been interpreted by Beremblum's "two-stage carcinogenesis theory"1) of initiation and promotion. Recently, it has been reported that promoters rather than initiators control carcinogenesis ${ }^{2)}$ for example, polybrominated biphenyl compounds, known as strong carcinogens, may act as promoters and not as initiators. ${ }^{3)}$ Early detection of promoters as well as initiators, therefore, is necessary for the prevention of cancer. Since the promoter test ${ }^{1)}$ using mice is a lengthy operation, quicker promoter test systems have been developed using the following biological activities of the most potent promoter, 12- $O$-tetradecanoyl-phorbol-13-acetate (TPA): the induction of ornithine decarboxylase (ODC) in mouse skin, ${ }^{4}$ the induction of terminal differentiation in human promyelocytic leukemia cells, ${ }^{5)}$ the inhibition of spontaneous and induced differentiation of murine erythroleukemia cells, ${ }^{6)}$ the induction of the early antigen of Epstein-Barr virus (EBVEA) ${ }^{7)}$ the inhibition of cell-cell communication, ${ }^{8)}$ and the activation of proteinkinase
C. ${ }^{9)}$

We have been searching widely for promoters in familiar plants, ${ }^{10)}$ using the EBV-EA induction or ODC induction test. From the standpoint of environmental carcinogenesis, however, not only plants but also microorganisms are noteworthy, especially in Japan, where fermented foods are common. This prompted us to search for promoters produced by microorganisms. Using the EBV-EA induction test, we screened Actinomycetes, from which two potent promoters, teleocidin A and $\mathrm{B}$, had been isolated. ${ }^{11)}$ Among about 3000 strains tested, we found one strain, NA34-17, showing EBV-EA induction, and isolated the active compounds A (AC-A) and B (AC-B) along with a small amount of teleocidin B (3) from the cultured broth. This paper deals with the isolation and structures of these compounds.

NA34-17 was cultured by deep aerated fermentation for $70 \mathrm{hr}$, and the filtered broth was extracted with ethyl acetate. The ethyl acetate extract was chromatographed on silica gel with

\footnotetext{
$\dagger$ To whom inquiries should be addressed.
} 


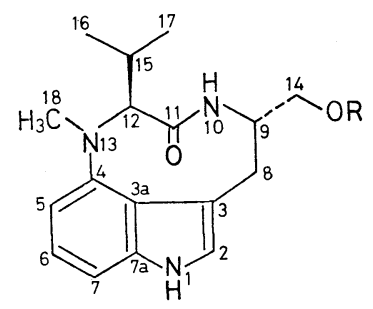

$\mathrm{R}=\mathrm{H}$ : Active compound. $A(1)$

$R=A c$ : Active compound $B(2)$

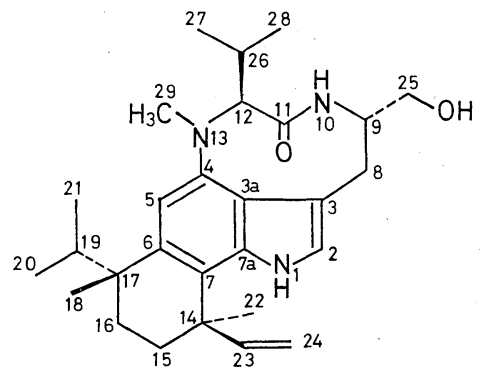

Teleocidin B (3)

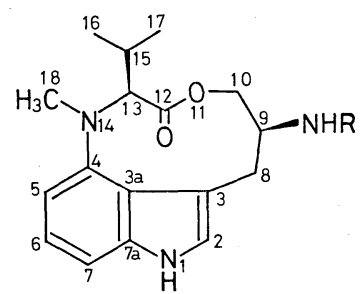

$R=H:(4) \quad R=A C:(7)$

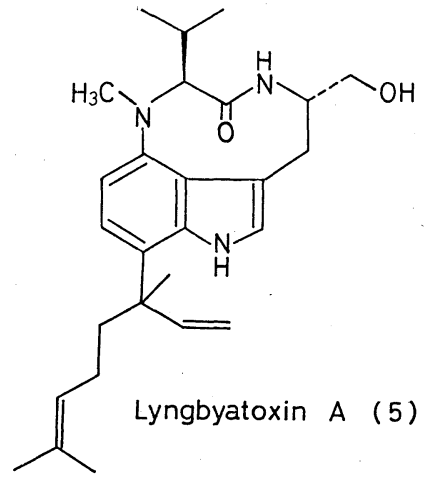

acetone-toluene mixtures to give three active fractions; 20,30 , and $40 \%$ acetone eluates. The $40 \%$ acetone eluate was purified by ODS column chromatography to give AC-A $(700 \mathrm{mg})$. Fractionation of the 20 and $30 \%$ acetone eluates by ODS column chromatography followed by preparative high performance liquid chromatography (HPLC) led to the isolation of AC-B $(8.2 \mathrm{mg})$ and teleocidin B $(3,9.2 \mathrm{mg})$, respectively.

The molecular formula of AC-A was established to be $\mathrm{C}_{17} \mathrm{H}_{23} \mathrm{~N}_{3} \mathrm{O}_{2}$ by high-resolution electron ionization mass spectroscopy (HREIMS): observed $m / z, 301.17907$; calculated $m / z, 301.17903$. The presence of the indole chromophore in AC-A was revealed by its UV spectrum $\left[\lambda_{\max }^{\mathrm{EtOH}} \mathrm{nm} \quad(\varepsilon): 301 \quad(7900), 229\right.$ $(28,100)]$, together with IR absorption bands at $1610,1565,1500 \mathrm{~cm}^{-1}$ and eight aromatic carbons in the ${ }^{13} \mathrm{C}$ NMR spectrum of AC-A. Acetylation of AC-A with acetic anhydridepyridine gave the monoacetate (2) whose ${ }^{1} \mathrm{H}$ NMR spectrum showed an $A B$ quartet ascribable to hydroxymethyl shifted upfield com-

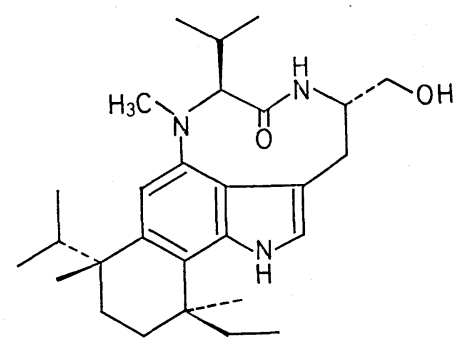

Dihydroteleocidin B (6) pared with those of AC-A. The IR spectrum of AC-A exhibited an amide carbonyl absorption at $1650 \mathrm{~cm}^{-1}$. Acid hydrolysis of AC-A gave the lactone amine (4) (IR $v_{\max }^{\mathrm{KBr}} \mathrm{cm}^{-1}: 1730$ ), which was easily reversed to AC-A by alkaline treatment. This fact indicated that a primary alcohol and an amide bond in AC-A were located near each other. The mass spectrum of AC-A showed the fragment ions at $m / z 301$ $\left(\mathrm{M}^{+}\right), 270\left(\mathrm{M}^{+}-\mathrm{CH}_{2} \mathrm{OH}\right)$, and $258\left(\mathrm{M}^{+}-\right.$ $\mathrm{C}_{3} \mathrm{H}_{7}$ ), supporting the presence of a primary alcohol and a propyl moiety.

The ${ }^{1} \mathrm{H}$ NMR spectrum of AC-A indicated the presence of an $N$-substituted methyl at $\delta 2.92(3 \mathrm{H}, \mathrm{s})$; an isopropyl at $\delta 2.59(1 \mathrm{H}, \mathrm{m})$, $0.63(3 \mathrm{H}, \mathrm{d})$, and $0.93(3 \mathrm{H}, \mathrm{d})$; a hydroxymethyl at $\delta 3.57(1 \mathrm{H}, \mathrm{m})$ and $3.74(1 \mathrm{H}, \mathrm{m})$; a methylene at $\delta 3.05(1 \mathrm{H}, \mathrm{dd})$ and $3.17(1 \mathrm{H}, \mathrm{d})$; two methines at $\delta 4.31(1 \mathrm{H}$, br. s) and $4.40(1 \mathrm{H}$, d) ; four aromatic protons at $\delta 6.50(1 \mathrm{H}, \mathrm{d})$, $6.89(1 \mathrm{H}, \mathrm{s}), 6.90(1 \mathrm{H}, \mathrm{d})$, and $7.06(1 \mathrm{H}, \mathrm{dd})$; and two NH protons at $\delta 7.37(1 \mathrm{H}$, br. s) and $8.02(1 \mathrm{H}$, br. s). The spectrum was very similar to that of lyngbyatoxin A (5). ${ }^{12)}$ In the ${ }^{1} \mathrm{H}$ 
NMR spectrum of AC-A, all the proton signals of 5, except for the protons of the monoterpene moiety at C-7, were observed. Furthermore, the ${ }^{1} \mathrm{H}$ NMR spectrum of AC-A exhibited four well-separated aromatic protons at $\delta 6.50(1 \mathrm{H}, \mathrm{d}, J=7.6 \mathrm{~Hz}), 6.89(1 \mathrm{H}, \mathrm{s}), 6.90$ $(1 \mathrm{H}, \mathrm{d}, J=7.3 \mathrm{~Hz})$, and $7.06(1 \mathrm{H}, \mathrm{dd}, J=7.6$ and $7.3 \mathrm{~Hz}$ ), which indicated that the monoterpene moiety at $\mathrm{C}-7$ of lyngbyatoxin $\mathrm{A}$ was replaced by a hydrogen in AC-A. This assignment was supported by the ${ }^{13} \mathrm{C}$ NMR spectrum of AC-A.

AC-A has two asymmetric centers and is optically active. The circular dichroism (CD) spectrum of AC-A was similar to that of dihydroteleocidin B (6), ${ }^{12)}$ suggesting that AC$A$ and 6 have the same absolute configuration in the nine-membered lactam ring. This was also supported by the presence of teleocidin B (3) in the cultured broth of NA34-17, since AC-A seems to be biosynthesized through the same pathway as that of teleocidin B. From the above data, AC-A is shown to have the structure 1, which was quite recently synthesized by Endo et al. and termed (-)-indolactam V. ${ }^{13,14)}$ AC-A had the same CD spectrum as that of (-)-indolactam V. ${ }^{15)}$ AC-B, a new metabo- lite, was identified as the 14- $O$-acetate of 1 by its comparison of the spectral data of 2 derived from 1.

Moore et al. ${ }^{12)}$ have reported that several signals in the ${ }^{1} \mathrm{H}$ NMR spectrum of lyngbyatoxin $\mathrm{A}$ were doubled in a 5:1 ratio. They performed a temperature study and suggested that the doubling of singnals could be due to two conformations of the toxin. They could not exclude, however, the possibility that lyngbyatoxin A was a mixture of two structural isomers in which the side chain was substituted at $\mathrm{C}-5$ or $\mathrm{C}-7$.

In the ${ }^{1} \mathrm{H}$ NMR spectrum of 1 the signals were doubled in a 4:1 ratio as in lyngbyatoxin $\mathrm{A}$, and in that of $\mathbf{2}$ the singals were doubled in a 2: 1 ratio. In the ${ }^{1} \mathrm{H}$ NMR spectrum of the 9$\mathrm{N}$-acetate of 5 (7) derived from 1 , however, the singnals were not doubled. These results strongly suggested that the doubling singnals could be ascribed to the conformers of the nine-membered lactam ring and not to the structural isomers. We first attempted a temperature study at $80 \mathrm{MHz}$ in deuterated dimethyl sulfoxide and pyridine. Although some signal changes were observed in both solvents, the evidence of the existence of two conform-

Table I. EBA-EA Inducing Activity by Teleocidin-Related

Compounds in Raji Cells ${ }^{a}$

\begin{tabular}{|c|c|c|c|c|c|c|c|}
\hline Compound & $\begin{array}{l}\text { Conc. } \\
\mu \mathrm{g} / \mathrm{ml}\end{array}$ & $\begin{array}{c}\text { Ratio of } \\
\text { EA-positive } \\
\text { cells }(\%)\end{array}$ & $\begin{array}{l}\text { Ratio of } \\
\text { viability of } \\
\text { cells }(\%)\end{array}$ & Compound & $\begin{array}{l}\text { Conc. } \\
\mu \mathrm{g} / \mathrm{ml}\end{array}$ & $\begin{array}{c}\text { Ratio of } \\
\text { EA-positive } \\
\text { cells }(\%)\end{array}$ & $\begin{array}{l}\text { Ratio of } \\
\text { viability of } \\
\text { cells }(\%)\end{array}$ \\
\hline \multirow{2}{*}{$n$-Butyric acid ${ }^{b}$} & \multirow[t]{2}{*}{352.0} & \multirow[t]{2}{*}{0.1} & \multirow[t]{2}{*}{55.6} & \multirow[t]{4}{*}{3} & 5.0 & 19.8 & 72.3 \\
\hline & & & & & 1.0 & 18.2 & 68.0 \\
\hline \multirow{2}{*}{ TPA } & \multirow[t]{2}{*}{0.02} & \multirow[t]{2}{*}{30.1} & \multirow[t]{2}{*}{80.6} & & 0.2 & 28.0 & 74.4 \\
\hline & & & & & 0.04 & 32.0 & 69.3 \\
\hline \multirow[t]{5}{*}{1} & 25.0 & 26.8 & 60.0 & \multirow{5}{*}{4} & 0.008 & 19.0 & 51.6 \\
\hline & 5.0 & 32.6 & 70.6 & & & & \\
\hline & 1.0 & 20.7 & 64.0 & & 25.0 & 16.5 & 67.4 \\
\hline & \multirow[t]{2}{*}{0.2} & \multirow[t]{2}{*}{22.2} & \multirow[t]{2}{*}{64.6} & & 5.0 & 12.1 & 77.1 \\
\hline & & & & & 1.0 & 16.4 & 64.9 \\
\hline \multirow[t]{5}{*}{2} & 25.0 & 12.3 & 79.1 & \multirow{5}{*}{7} & 0.2 & 5.7 & 55.3 \\
\hline & 5.0 & 30.4 & 62.3 & & & & \\
\hline & 1.0 & 22.6 & 75.2 & & 5.0 & 0.1 & 73.8 \\
\hline & \multirow[t]{2}{*}{0.2} & \multirow[t]{2}{*}{12.1} & \multirow[t]{2}{*}{55.0} & & 1.0 & 1.7 & 57.7 \\
\hline & & & & & 0.2 & 0.1 & 43.6 \\
\hline
\end{tabular}

a In this table the data at several different concentrations, in the range of which maximum induction was observed, are listed.

${ }^{b} \quad n$-Butyric acid was added to all samples to enhance the sensitivity of Raji cells, and regarded as a control. ${ }^{17)}$ 
ers could not be obtained. Subsequently, 1 was analyzed by HPLC using a $\mu$-Porasil column with a mixture of chloroform and 2propanol $(95: 5)$. When the column and solvent were cooled below $-10^{\circ} \mathrm{C}, 1$ separated into two peaks. Each peak was collected at room temperature. Both the ${ }^{1} \mathrm{H}$ NMR spctra coincided with that of 1 , confirming that 1 was present as two conformational isomers at room temperature.

The EBV-EA inducing activities of 1 and its related compounds are summarized in Table I. It has been known that Raji cells treated with chemical compounds such as promoters produce the early antigen (EA) before the activation of EBV. This EA can be easily detected by an indirect immunofluorescence technique. ${ }^{16)}$ The EBV-EA inducing activity is estimated by the ratio $(\%)$ of EA-positive cells. Compound 1 showed an EBV-EA inducing activity although it was less active than TPA and teleocidin B (3). Compound 2, the 14-O-acetate of 1 , was as active as 1 while 4 had only a little activity, and 7 had no activity. The activity of $\mathbf{4}$ appeared to be caused by 1 formed by the isomerization of 4 . These indicate that the nine-membered lactam ring is essential for the EBV-EA induction. This ring moiety has also been found to be important for the induction of ODC, the adhesion of human promyelocytic leukemia cells, the transformation of BALB 3T3 (A31-1-1) cells, and the binding ability to a TPA receptor, by using four synthetic indolactam V diastereomers. ${ }^{13)}$

Several modification of the functional group at $\mathrm{C}-14$ are expected to give important informations about the mechanism of the EBV-EA induction. The relationship between the structure and the EBV-EA inducing activity of 1 and its derivatives will be discussed in a subsequent report.

\section{EXPERIMENTAL}

The following spectroscopic and analytical instruments were used: UV, Shimadzu UV-200; ORD, Jasco Model J5; ${ }^{1} \mathrm{H}$ NMR, Hitachi Model R-22 (90 MHz) and JEOL GX $400 \quad(400 \mathrm{MHz}) ;{ }^{13} \mathrm{C}$ NMR, JEOL GX 400 $(100 \mathrm{MNz})$; IR, Shimadzu Model 435; HPLC, Waters
Model M 6000A with a UV detector; CD, Jasco Model J500 ; MS, JEOL JMS-DX 300.

HPLC was carried out on YMC packed S-343 column (Yamamura Chemical Laboratory), $\mu$-Porasil (Waters Associates) and semi preparative $\mu$-Bondapak- $\mathrm{C}_{18}$ (Waters Associates). Wako C-200 gel (Wako Pure Chemical Industries) and YMC I-40/64 gel (Yamamura Chemical Laboratory) were used for column chromatography.

Isolation and cultivation of microorganisms. Test strains were isolated from soil by the conventional methods. Each of about 3000 isolates of Actinomycetes was inoculated into test tubes $(2.4 \mathrm{~cm} \times 20 \mathrm{~cm})$ with a medium $(10 \mathrm{ml})$ consisting of $1 \%$ glucose, $1 \%$ polypeptone (Daigo Eiyo Kagaku), $1 \%$ meat extract (Wako Pure Chemicals), and $0.5 \% \mathrm{NaCl}$ ( $\mathrm{pH} \mathrm{7.0)}$. After shaking at $30^{\circ} \mathrm{C}$ for 3 to 4 days, the cultured broth was filtered. The filtrate was used for the assay of EBV-EA induction at concentrations of 10,2, and $0.4 \mu \mathrm{l} / \mathrm{ml}$ DMSO.

Strain NA34-17 kept on Waksman's medium was transferred to a $500 \mathrm{ml}$ shaking flask containing $100 \mathrm{ml}$ of the medium mentioned above, and the flask was shaken at $30^{\circ} \mathrm{C}$ for $50 \mathrm{hr}$. The seed culture thus obtained was transferred to a 30-liter jar fermentor (Marubishi type MSJ-U2) containing 20 liters of medium. The conditions of the cultivation were as follows: medium, $2 \%$ glucose, $1 \%$ polypeptone, $1 \%$ meat extract, $0.5 \% \mathrm{NaCl}, 0.05 \%$ adekanol; initial $\mathrm{pH}, 7.0$; temperature, $30^{\circ} \mathrm{C}$; aeration, 22 liters/min; agitation, $400 \mathrm{rpm}$.

Isolation of 1, 2, and 3 . The cultured filtrate (40 liters) was concentrated to 4 liters in vacuo at $40^{\circ} \mathrm{C}$ and then extracted with 10 liters of EtOAc. The EtOAc layer was dried over sodium sulfate and evaporated in vacuo to give a brown oily syrup $(13 \mathrm{~g})$. The residue was chromatographed on Wako C-200 gel (500 g), eluting with toluene containing increasing amounts of acetone to give three active fractions: I ( $20 \%$ acetone, $1.26 \mathrm{~g})$, II ( $30 \%$ acetone, $1.18 \mathrm{~g})$, and III $(40 \%$ acetone, $5.66 \mathrm{~g})$. Fraction I was chromatographed on $160 \mathrm{~g}$ of YMC gel I-40/64 with 1 liter of a linear gradient of $\mathrm{MeOH}$-water, starting with $50 \%$ $\mathrm{MeOH}$ and ending with $100 \% \mathrm{MeOH}$. The active fraction (42.6 mg) eluted with the $\mathrm{MeOH}$-water mixture (at $600 . \mathrm{ml}-$ $735 \mathrm{ml}$ elution) was further purified by HPLC on semi prep. $\mu$-Porasil with $30 \%$ EtOAc in hexane, followed by HPLC on semi prep. $\mu$-Bondapak- $\mathrm{C}_{18}$ with $60 \% \mathrm{MeOH}$ in water to give $2(8.2 \mathrm{mg})$ as a colorless powder $(\mathrm{mp}$ $\left.100 \sim 110^{\circ} \mathrm{C}\right) .{ }^{1} \mathrm{H}$ NMR $\delta_{\mathrm{Me}_{4} \mathrm{Si}}^{\mathrm{CDCl}_{3}}$ : Major conformer; 0.64 $\left(3 \mathrm{H}, \mathrm{d}, J_{15,16}=6.7 \mathrm{~Hz}, \mathrm{H}_{3}-16\right), 0.93\left(3 \mathrm{H}, \mathrm{d}, J_{15,17}=6.1 \mathrm{~Hz}\right.$, $\left.\mathrm{H}_{3}-17\right), 2.09(3 \mathrm{H}, \mathrm{s}, \mathrm{Ac}), 2.61(1 \mathrm{H}, \mathrm{m}, \mathrm{H}-15), 2.93(3 \mathrm{H}, \mathrm{s}$, $\left.\mathrm{H}_{3}-18\right), 3.09\left(1 \mathrm{H}, \mathrm{dd}, J_{g e m}=17.7 \mathrm{~Hz}, J_{8 \mathrm{a}, 9}=4.0 \mathrm{~Hz}, \mathrm{Ha}-8\right)$, $3.24\left(1 \mathrm{H}, \mathrm{d}, J_{\text {gem }}=17.7 \mathrm{~Hz}, \mathrm{Hb}-8\right), 3.99\left(1 \mathrm{H}, \mathrm{dd}, J_{g e m}=\right.$ $\left.11.5 \mathrm{~Hz}, J_{9,14 \mathrm{a}}=8.5 \mathrm{~Hz}, \mathrm{Ha}-14\right), 4.20\left(1 \mathrm{H}, \mathrm{dd}, J_{g e m}=\right.$ $\left.11.5 \mathrm{~Hz}, J_{9,14 \mathrm{~b}}=3.5 \mathrm{~Hz}, \mathrm{Hb}-14\right), 4.36\left(1 \mathrm{H}, \mathrm{d}, J_{12,15}=\right.$ $10.4 \mathrm{~Hz}, \mathrm{H}-12), 4.51(1 \mathrm{H}$, br. s, H-9), $6.01(1 \mathrm{H}$, br. s, NH10), $6.53\left(1 \mathrm{H}, \mathrm{d}, J_{5,6}=7.6 \mathrm{~Hz}, \mathrm{H}-5\right), 6.90(1 \mathrm{H}, \mathrm{s}, \mathrm{H}-2), 6.91$ 
$\left(1 \mathrm{H}, \mathrm{d}, J_{6,7}=7.9 \mathrm{~Hz}, \mathrm{H}-7\right), 7.07\left(1 \mathrm{H}, \mathrm{dd}, J_{5,6}=7.6 \mathrm{~Hz}\right.$, $\left.J_{6,7}=7.9 \mathrm{~Hz}, \mathrm{H}-6\right), 8.03$ (1H, br. s, NH-1). Minor conformer; $0.94(\mathrm{~d}, J=6.1 \mathrm{~Hz}), 1.24(\mathrm{~d}, J=6.7 \mathrm{~Hz}), 2.02(\mathrm{~s}), 2.40$ (m), 2.75 (s), 2.78 (d, $J=14.5 \mathrm{~Hz}), 2.98$ (d, $J=10.7 \mathrm{~Hz}$ ), 3.12 (dd, $J=14.5 \mathrm{~Hz}, 5.5 \mathrm{~Hz}$ ), 3.85 (m), 4.61 (br. s), 6.98 (br. s), 7.04 (d, $J=7.5 \mathrm{~Hz}), 7.16$ (dd, $J=7.5 \mathrm{~Hz}, 7.5 \mathrm{~Hz}$ ), 7.27 (s), 7.28 (d, $J=7.5 \mathrm{~Hz}$ ), 8.30 (br. s). UV $\lambda_{\max }^{\mathrm{EtOH}} \mathrm{nm}(\varepsilon)$ : 295 (7200), $227(27,800)$. IR $v_{\max }^{\mathrm{KBr}} \mathrm{cm}^{-1}: 3350,2950,1735$, $1660,1605,1500,1365,1240,1040,745 .[\alpha]_{\mathrm{D}}^{26}-57^{\circ}(c=$ 0.315, EtOH). HR-EIMS $m / z: 343.19023 \quad\left(\mathrm{M}^{+}\right.$, $\mathrm{C}_{19} \mathrm{H}_{25} \mathrm{~N}_{3} \mathrm{O}_{3}$; calcd. 343.18959).

Fraction II was fractionated by column chromatography on Wako C-200 gel $(30 \mathrm{~g})$ with toluene $(200 \mathrm{ml})$ and EtOAc $(200 \mathrm{ml})$ by gradient elution to give an active fraction $(42.2 \mathrm{mg})$, which was further purified by HPLC on Radialpak $\mu$-Bondapak- $\mathrm{C}_{18}$ with $80 \% \mathrm{MeOH}$ in water to yield $3(9.2 \mathrm{mg})$ as a colorless powder $\left(\mathrm{mp} 137 \sim 150^{\circ} \mathrm{C}\right)$. ${ }^{1} \mathrm{H} \mathrm{NMR} \delta_{\mathrm{Me}_{4} \mathrm{Si}}^{\mathrm{CDCl}_{3}}$ : Major conformer; $0.54\left(3 \mathrm{H}, \mathrm{d}, J_{19,20}=\right.$ $\left.6.7 \mathrm{~Hz}, \mathrm{H}_{3}-20\right), 0.69\left(3 \mathrm{H}, \mathrm{d}, J_{26,27}=6.7 \mathrm{~Hz}, \mathrm{H}_{3}-27\right), 0.92$ $\left(3 \mathrm{H}, \mathrm{d}, J_{26,28}=6.4 \mathrm{~Hz}, \mathrm{H}_{3}-28\right), 1.01\left(3 \mathrm{H}, \mathrm{d}, J_{19,21}=6.4 \mathrm{~Hz}\right.$, $\left.\mathrm{H}_{3}-21\right), 1.35$ (3H, s, $\mathrm{H}_{3}-18$ or 22$), 1.44\left(2 \mathrm{H}, \mathrm{m}, \mathrm{H}_{2}-15\right.$ or 16), $1.51\left(3 \mathrm{H}, \mathrm{s}, \mathrm{H}_{3}-18\right.$ or 22$), 1.90\left(2 \mathrm{H}, \mathrm{d}, J_{\text {gem }}=10.1 \mathrm{~Hz}\right.$, $\mathrm{H}_{2}-15$ or 16$), 2.25$ (1H, m, H-19), 2.62 (1H, m, H-26), 2.90 $\left(3 \mathrm{H}, \mathrm{s}, \mathrm{H}_{3}-29\right), 2.99\left(1 \mathrm{H}, \mathrm{dd}, J_{g e m}=17.7 \mathrm{~Hz}, J_{8 \mathrm{a}, 9}=3.4 \mathrm{~Hz}\right.$, $\mathrm{Ha}-8), 3.13\left(1 \mathrm{H}, \mathrm{d}, J_{\text {gem }}=17.7 \mathrm{~Hz}, \mathrm{Hb}-8\right), 3.53(1 \mathrm{H}, \mathrm{m}, \mathrm{Ha}-$ 25), $3.72(1 \mathrm{H}, \mathrm{m}, \mathrm{Hb}-25), 4.31\left(1 \mathrm{H}, \mathrm{d}, J_{12,26}=10.1 \mathrm{~Hz}, \mathrm{H}-\right.$ 12), ca. $4.3\left(1 \mathrm{H}\right.$, br. m, H-9), $5.25\left(1 \mathrm{H}, \mathrm{d}, J_{\text {cis }}=10.7 \mathrm{~Hz}\right.$, Ha-24), $5.41\left(1 \mathrm{H}, \mathrm{d}, J_{\text {trans }}=17.7 \mathrm{~Hz}, \mathrm{Hb}-24\right), 6.16(1 \mathrm{H}, \mathrm{dd}$, $\left.J_{\text {cis }}=10.7 \mathrm{~Hz}, J_{\text {trans }}=17.7 \mathrm{~Hz}, \mathrm{H}-23\right), 6.51(1 \mathrm{H}, \mathrm{s}, \mathrm{H}-5)$, $6.78(1 \mathrm{H}, \mathrm{s}, \mathrm{H}-2), 7.26(1 \mathrm{H}, \mathrm{s}, \mathrm{NH}-10), 8.67(1 \mathrm{H}, \mathrm{s}, \mathrm{NH}-1)$. Minor conformer ; $0.61(\mathrm{~d}, J=6.7 \mathrm{~Hz}), 0.93(\mathrm{~d}, J=6.4 \mathrm{~Hz})$, $1.03(\mathrm{~d}, J=6.7 \mathrm{~Hz}), 1.25(\mathrm{~d}, J=6.7 \mathrm{~Hz}), 1.50(\mathrm{~s}), 2.73$ (s). Other peaks had weak intensities and overlapped those of the major conformer. UV $\lambda_{\max }^{\mathrm{EtOH}} \mathrm{nm}(\varepsilon): 286$ (9100), 233 $(29,500)$. IR $v_{\max }^{\mathrm{KBr}} \mathrm{cm}^{-1}: 3440,3375,3075,1648,1600$, $1548,1503,1465,1450,1408,1372,1055,978,913 .[\alpha]_{D}^{26}$ $-150^{\circ}(c=0.273, \mathrm{EtOH}) . \mathrm{CD}[\theta]_{309}+3200,[\theta]_{299} 0,[\theta]_{252}$ $-24,900,[\theta]_{237}-31,600,[\theta]_{224}-38,300,[\theta]_{205} 0(c=$ $\left.8.4 \times 10^{-3}, \mathrm{MeOH}\right)$. HR-EIMS $m / z: 451.32011\left(\mathrm{M}^{+}\right.$, $\mathrm{C}_{28} \mathrm{H}_{41} \mathrm{~N}_{3} \mathrm{O}_{2}$; calcd. 451.31988).

Fraction III was chromatographed on $160 \mathrm{~g}$ of YMC I$40 / 64$ gel with $60 \% \mathrm{MeOH}$ in water to give a yellow powder $(700 \mathrm{mg})$, which was recrystallized from EtOHwater to yield colorless needles $1\left(\mathrm{mp} 130 \sim 165^{\circ} \mathrm{C}\right) .{ }^{1} \mathrm{H}$ NMR $\delta_{\mathrm{Me}_{4} \mathrm{Si}}^{\mathrm{CDCl}_{3}}$ : Major conformer; $0.63\left(3 \mathrm{H}, \mathrm{d}, J_{15,16}=\right.$ $\left.6.7 \mathrm{~Hz}, \mathrm{H}_{3}-16\right), 0.93\left(3 \mathrm{H}, \mathrm{d}, J_{15,17}=6.4 \mathrm{~Hz}, \mathrm{H}_{3}-17\right), 2.59$ $(1 \mathrm{H}, \mathrm{m}, \mathrm{H}-15), 2.92\left(3 \mathrm{H}, \mathrm{s}, \mathrm{H}_{3}-18\right), 3.05\left(1 \mathrm{H}, \mathrm{dd}, J_{\text {gem }}=\right.$ $\left.17.4 \mathrm{~Hz}, J_{8 \mathrm{a}, 9}=3.7 \mathrm{~Hz}, \mathrm{Ha}-8\right), 3.17\left(1 \mathrm{H}, \mathrm{d}, J_{\text {gem }}=17.4 \mathrm{~Hz}\right.$, $\mathrm{Hb}-8), 3.57$ (1H, m, Ha-14), 3.74 (1H, m, Hb-14), 4.31 $\left(1 \mathrm{H}\right.$, br. s, H-9), $4.40\left(1 \mathrm{H}, \mathrm{d}, J_{12,15}=10.4 \mathrm{~Hz}, \mathrm{H}-12\right), 6.50$ $\left(1 \mathrm{H}, \mathrm{d}, J_{5,6}=7.6 \mathrm{~Hz}, \mathrm{H}-5\right), 6.89(1 \mathrm{H}, \mathrm{s}, \mathrm{H}-2), 6.90(1 \mathrm{H}, \mathrm{d}$, $\left.J_{6,7}=7.3 \mathrm{~Hz}, \mathrm{H}-7\right), 7.06\left(1 \mathrm{H}, \mathrm{dd}, J_{5,6}=7.6 \mathrm{~Hz}, J_{6,7}=\right.$ $7.3 \mathrm{~Hz}, \mathrm{H}-6), 7.37$ (1H, br. s, NH-10), 8.02 (1H, br. s, NH1). Minor conformer; $0.93(\mathrm{~d}, J=6.4 \mathrm{~Hz}), 1.25(\mathrm{~d}, J=$ $6.7 \mathrm{~Hz}), 2.75(\mathrm{~s})$. Other peaks had weak intensities and overlapped those of the major conformer. ${ }^{13} \mathrm{C}$ NMR $\delta_{\mathrm{Me}_{4} \mathrm{Si}_{3}}^{\mathrm{CDCl}_{3}}$ : Major conformer; 174.6 (s), 147.5 (s), 139.4 (s),
122.4 (d), 121.7 (d), 117.9 (s), 113.8 (s), 106.1 (d), 104.3 (d), $70.9(\mathrm{~d}), 64.6(\mathrm{t}), 56.0(\mathrm{~d}), 33.8(\mathrm{t}), 32.9(\mathrm{q}), 28.4(\mathrm{~d}), 21.5$ (q), 19.4 (q). Minor conformer; 173.0 (s), 145.0 (s), 127.9 (s), $125.8(\mathrm{~d}), 110.5(\mathrm{~d}), 107.6(\mathrm{~s}), 76.5(\mathrm{~d}), 62.0(\mathrm{t}), 55.0(\mathrm{~d})$, 35.7 (q), 28.4 (t), 24.4 (d), 19.4 (q). Other peaks overlapped those of the major conformer. IR $v_{\max }^{\mathrm{KBr}} \mathrm{cm}^{-1}: 3370,2950$, $1650,1610,1565,1500,1275,1040,780,740 .[\alpha]_{\mathrm{D}}^{27}-170^{\circ}$ $(c=0.499, \mathrm{EtOH}) . \mathrm{CD}[\theta]_{304}+8700,[\theta]_{291} 0,[\theta]_{242}$ $-22,100, \quad[\theta]_{221} \quad-47,900, \quad[\theta]_{207} \quad 0 \quad\left(c=1.04 \times 10^{-2}\right.$, $\mathrm{MeOH})$. EIMS $m / z: 301\left(\mathrm{M}^{+}, 36.6\right), 270$ (3.7), 258 (9.8), 215 (41.5), 185 (19.5), 171 (100), 155 (37.8), 143 (13.9), 130 (33.7), 115 (15.9), 103 (14.1), 77 (17.1), 41 (25.1).

Acetylation of $\mathbf{1}$. Compound $1(14.1 \mathrm{mg})$ was dissolved in dry pyridine $(0.5 \mathrm{ml})$ and acetic anhydride $(0.5 \mathrm{ml})$, and the solution was allowed to stand at room temperature for two days. After adding crushed ice, the reaction mixture was extracted with EtOAc. This extract was purified by HPLC on semi prep. $\mu$-Bondapak- $\mathrm{C}_{18}$ with $65 \% \mathrm{MeOH}$ in water. Compound $2(8.6 \mathrm{mg})$ was obtained as a colorless powder (mp $98 \sim 110^{\circ} \mathrm{C}$ ).

Acid hydrolysis of 1. An ethanol solution of 1 (43.2 mg) was put into a test tube and evaporated in vacuo. To the tube, $0.3 \mathrm{ml}$ of $6 \mathrm{~N} \mathrm{HCl}$ was added and the tube was sealed and heated at $120^{\circ} \mathrm{C}$ for $4 \mathrm{hr}$. The resultant solution was evaporated in vacuo to dryness and dissolved in a small amount of EtOH. Careful addition of EtOAc to the EtOH solution gave fine crystals which were filtered off and dissolved in water. To this solution, a small amount of $\mathrm{NaHCO}_{3}$ was added and the solution was extracted two times with EtOAc. The EtOAc layer was washed with water, dried over sodium sulfate, and evaporated in vacuo to dryness. The EtOAc extract was purified by column chromatography on Wako C-200 gel (1.8 g), eluting with $\mathrm{CHCl}_{3}$ containing increasing amounts of $\mathrm{MeOH}$. The eluates with $10.0,12.5,15.0$ and $17.5 \% \mathrm{MeOH}$ were combined at $c a .0^{\circ} \mathrm{C}$ and evaporated in vacuo at $c a .5^{\circ} \mathrm{C}$ to give colorless needles $(19.3 \mathrm{mg})$. The needles were washed with water and dried over sodium sulfate to yield 4 (12 mg, mp $\left.149 \sim 152^{\circ} \mathrm{C}\right) .{ }^{1} \mathrm{H}-\mathrm{NMR} \delta_{\mathrm{Me}_{4} \mathrm{Si}}^{\mathrm{CDCl}_{3}}$ : Major conformer; $1.10(3 \mathrm{H}, \mathrm{d}), 1.15(3 \mathrm{H}, \mathrm{d}), 2.40(1 \mathrm{H}, \mathrm{m}), 2.80(3 \mathrm{H}, \mathrm{s}), 3.40$ $(1 \mathrm{H}, \mathrm{d}), 2.90 \sim 3.70(3 \mathrm{H}, \mathrm{m}), 3.85(1 \mathrm{H}, \mathrm{dd}), 3.95(1 \mathrm{H}, \mathrm{dd})$, $7.00 \sim 7.20(4 \mathrm{H}, \mathrm{m})$. Minor conformer; $0.83(\mathrm{~d}), 1.33(\mathrm{~d})$. Other peaks had weak intensities and overlapped those of the major conformer. UV $\lambda_{\max }^{\mathrm{EtOH}} \mathrm{nm}(\varepsilon): 292.5$ (5900), 286 (6100), $226(26,900)$. IR $v_{\max }^{\mathrm{KBr}} \mathrm{cm}^{-1}: 3620,3400,3340$, 3170, 2960, 2800, 1730, 1615, 1600, 1500, 1390, 1080, 1020, 745. $[\alpha]_{\mathrm{D}}^{27}-35^{\circ}(c=0.130$, EtOH $)$. HR-EIMS $m / z$ : 301.17946 $\left(\mathrm{M}^{+}, \mathrm{C}_{17} \mathrm{H}_{23} \mathrm{~N}_{3} \mathrm{O}_{2}\right.$; calcd. 301.17903).

Acetylation of 4 . Compound $4(10 \mathrm{mg})$, pyridine $(0.5 \mathrm{ml})$, and acetic anhydride $(0.5 \mathrm{ml})$ were mixed and left to stand overnight at room temperature. The reaction mixture was purified by column chromatography on Wako C-200 gel $(1 \mathrm{~g})$, eluting with toluene containing increasing amounts of acetone, and followed by HPLC on semi prep. $\mu$ - 
Bondapak- $\mathrm{C}_{18}$ with $65 \% \mathrm{MeOH}$ to give 7 as a colorless powder (mp $110 \sim 115^{\circ} \mathrm{C}$ ). ${ }^{1} \mathrm{H}$ NMR $\delta_{\mathrm{Me}_{4} \mathrm{Si}_{3}}^{\mathrm{CDCl}_{3}} 1.05(3 \mathrm{H}, \mathrm{d}$, $\left.J_{15,16}=6 \mathrm{~Hz}, \mathrm{H}_{3}-16\right), 1.18\left(3 \mathrm{H}, \mathrm{d}, J_{15,17}=6.5 \mathrm{~Hz}, \mathrm{H}_{3}-17\right)$, 2.05 (3H, s, Ac), 2.33 (1H, m, H-15), $2.84\left(3 \mathrm{H}, \mathrm{s}, \mathrm{H}_{3}-18\right)$, $2.96\left(1 \mathrm{H}, \mathrm{dd}, J_{\text {gem }}=14 \mathrm{~Hz}, J_{8 \mathrm{a}, 9}=6 \mathrm{~Hz}, \mathrm{Ha}-8\right), 3.19(1 \mathrm{H}$, $\left.\mathrm{dd}, J_{g e m}=14 \mathrm{~Hz}, J_{8 \mathrm{~b}, 9}=10.5 \mathrm{~Hz}, \mathrm{Hb}-8\right), 3.34(1 \mathrm{H}, \mathrm{d}$, $\left.J_{13,16}=9.5 \mathrm{~Hz}, \mathrm{H}-13\right), 3.81\left(1 \mathrm{H}, \mathrm{dd}, J_{g e m}=12.5 \mathrm{~Hz}, J_{9,10 \mathrm{a}} \doteq\right.$ $5.5 \mathrm{~Hz}, \mathrm{Ha}-10), 4.06\left(1 \mathrm{H}, \mathrm{dd}, J_{\text {gem }}=12.5 \mathrm{~Hz}, J_{9,10 \mathrm{~b}}=2 \mathrm{~Hz}\right.$, Hb-10), $4.46\left(1 \mathrm{H}\right.$, br. s, H-9), $6.60\left(1 \mathrm{H}, \mathrm{d}, J_{5,6}=9 \mathrm{~Hz}, \mathrm{H}-\right.$ 5), $6.95 \sim 7.20$ (3H, m, indole ring), 8.58 (1H, br. s, NH-1). UV $\lambda_{\max }^{\mathrm{EOH}} \mathrm{nm}(\varepsilon): 287(6100), 225(28,400) . \mathrm{IR} v_{\max }^{\mathrm{KBr}} \mathrm{cm}^{-1}$ : 3390, 3290, 2970, 1725, 1655, 1535, 1500, 1265, 1185, 1025, 745. $[\alpha]_{\mathrm{D}}^{27}-35^{\circ}(c=0.259$, EtOH $)$. HR-EIMS $\mathrm{m} / \mathrm{z}$ : $343.19025\left(\mathrm{M}^{+}, \mathrm{C}_{19} \mathrm{H}_{25} \mathrm{~N}_{3} \mathrm{O}_{3}\right.$; calcd. 343.18959).

Temperature study of $\mathbf{1}$. In deuterated dimethyl sulfoxide at $140^{\circ} \mathrm{C}$, two doublets of the major conformer at $\delta 0.50$ and 0.78 , and those of the minor conformer at $\delta 0.78$ and 1.10 overlapped to give two doublets at $\delta 0.75$ and 0.82 . In deuterated pyridine at $110^{\circ} \mathrm{C}$, two doublets of the major conformer at $\delta 0.66$ and 1.05 , and those of the minor conformer at $\delta 0.92$ and 1.20 changed to one doublet at $\delta 0.98$ and one broad singlet at $\delta 0.84$, respectively.

HPLC analysis of $\mathbf{1}$. Compound $\mathbf{1}$ was analyzed by HPLC to give a single peak on five columns with various solvents at room temperature. The conditions were as follows (column, column size, solvent, flow rate, $t_{R}$ ): 1) Cosmosil $(5 \mathrm{Ph})$ packed column (Nakarai Chemicals, Ltd.), $4.6 \mathrm{~mm}$ i.d. $\times 150 \mathrm{~mm}, 60 \% \mathrm{MeOH}$ in water, $0.4 \mathrm{ml} / \mathrm{min}, 14.5 \mathrm{~min}$; 2) Cosmosil (5TMS) packed column (Nakarai Chemicals, Ltd.), $4.6 \mathrm{~mm}$ i.d. $\times 150 \mathrm{~mm}, 40 \%$ $\mathrm{MeOH}$ in water, $1.0 \mathrm{ml} / \mathrm{min}, 20.0 \mathrm{~min}$; 3) Cosmosil $\left(5 \mathrm{C}_{8}\right)$ packed column (Nakarai Chemicals, Ltd.), $4.6 \mathrm{~mm}$ i.d. $\times$ $150 \mathrm{~mm}, 70 \% \mathrm{MeOH}$ in water, $0.4 \mathrm{ml} / \mathrm{min}, 9.4 \mathrm{~min}$; 4) YMC packed A311 column, $4.0 \mathrm{~mm}$ i.d. $\times 100 \mathrm{~mm}, 60 \%$ $\mathrm{MeOH}$ in water, $1.0 \mathrm{ml} / \mathrm{min}, 8.5 \mathrm{~min}$; 5) $\mu$-Porasil, $4.0 \mathrm{~mm}$ i.d. $\times 300 \mathrm{~mm}, 60 \%$ EtOAc in hexane, $1.0 \mathrm{ml} / \mathrm{min}$, $24.6 \mathrm{~min}$; and 6) $\mu$-Porasil, $4.0 \mathrm{~mm}$ i.d. $\times 300 \mathrm{~mm}, 5 \%$ iso$\mathrm{PrOH}$ in $\mathrm{CHCl}_{3}, 1.0 \mathrm{ml} / \mathrm{min}, 7.4 \mathrm{~min}$.

Compound 1, however, gave two peaks $\left(t_{R}=5.2,7.6\right.$ min) by HPLC using $\mu$-Porasil with $5 \%$ iso-PrOH in $\mathrm{CHCl}_{3}$ (flow rate, $1.0 \mathrm{ml} / \mathrm{min}$ ) at $-17^{\circ} \mathrm{C}$. Each peak was collected under the following conditions: column, $\mu$ Porasil; column size, $4.0 \mathrm{~mm}$ i.d. $\times 300 \mathrm{~mm}$; solvent, $4 \%$ iso- $\mathrm{PrOH}$ in $\mathrm{CHCl}_{3}$; flow rate, $1.0 \mathrm{ml} / \mathrm{min}$; temperature of the column and solvent, $c a .-15^{\circ} \mathrm{C}$. Four runs of collection and concentration gave fraction $1 \quad\left(t_{R}=\right.$ $5.6 \sim 7.2 \mathrm{~min}, 43.2 \mathrm{mg})$ and fraction $2\left(t_{R}=9.4 \sim 11.1 \mathrm{~min}\right.$, $6.2 \mathrm{mg})$.

Acknowledgments. The authors express their thanks to $\mathrm{Mr}$. R. Imamura at the Faculty of Science, Kyoto University, for the $\mathrm{FT}-{ }^{1} \mathrm{H}$ and ${ }^{13} \mathrm{C}$ NMR measurements, to Mr. K. Kuwabara at Osaka Prefectural Institute of Public Health for the EIMS measurement, to Dr. T. Aoyama at JEOL for the HR-EIMS measurement, and to Dr. T. Matoba at the Research Institute for Food Science for the CD spectrum measurement.

\section{REFERENCES}

1) I. Berenblum, Cancer Res., 1, 807 (1941).

2) J. F. Morton, Cancer Res., 28, 2268 (1968).

3) G. Tsushimoto, J. E. Trosko, C. Chang and S. D. Aust, Carcinogenesis, 3, 181 (1982).

4) T. G. O'Brien, R. C. Simsiman and R. K. Boutwell, Cancer Res., 35, 2426 (1975).

5) E. Huberman and M. F. Callaham, Proc. Natl. Acad. Sci. U.S.A., 76, 1293 (1979).

6) H. Yamasaki, E. Fibach, U. Nudel, I. B. Weinstein, R. A. Rifkind and P. A. Marks, Proc. Natl. Acad. Sci. U.S.A., 74, 3451 (1977).

7) H. Hausen, G. W. Bornkamm, R. Schmidt and E. Hecker, Proc. Natl. Acad. Sci. U.S.A., 76, 782 (1979); Y. Ito, S. Yanase, J. Fujita, T. Harayama, M. Takashima and H. Imanaka, Cancer Lett., 13, 29 (1981).

8) L. P. Yotti, C. C. Chang and J. E. Trosko, Science, 206, 1089 (1979); A. M. Murray and D. J. Fitzgerald, Biochem. Biophys. Res. Commun., 91, 395 (1979).

9) M. Castagna, Y. Takai, K. Kaibuchi, K. Sano, U. Kikkawa and Y. Nishizuka, J. Biol. Chem., 257, 7847 (1982).

10) H. Ohigashi, T. Ohtsuka, M. Hirota, K. Koshimizu, H. Tokuda, and Y. Ito, Agric. Biol. Chem., 47, 1617 (1983); H, Ohigashi, M. Hirota, T. Ohtsuka, K. Koshimizu, H. Fujiki, M. Suganuma, Z. Yamaizumi and T. Sugimura, ibid., 46, 2605 (1982).

11) M. Takashima and H. Sakai, Bull. Agr. Chem. Soc. Jpn., 24, 647 (1960); M. Takashima and H. Sakai, ibid., 24, 652 (1960); M. Takashima, H. Sakai and K. Arima, Agric. Biol. Chem., 26, 660 (1962); M. Takashima, H. Sakai, R. Mori and K. Arima, ibid., 26, 669 (1962).

12) J. H. Cardellina II, F. J. Marner and R. E. Moore, Science, 204, 193 (1979).

13) Y. Endo, K. Shudo and T. Okamoto, Chem. Pharm. Bull., 30, 3457 (1982).

14) Y. Endo, K. Shudo and T. Okamoto, Abstract of Papers, Proceedings of the Japanese Cancer Association, the 42nd Annual Meeting, 1983, p. 53.

15) K. Shudo, personal communication, 1983.

16) W. Henle and G. Henle, J. Bacteriol., 91, 1248 (1966).

17) M. Kawanishi and Y. Ito, Cancer Lett., 11, 129 (1980). 